\title{
IL-15 is decreased upon CsA and FK506 treatment of acute rejection following heart transplantation in mice
}

\author{
ZHIYONG YU ${ }^{1-3}$, XIAOPING ZHOU ${ }^{1-3}$, SONGFENG YU ${ }^{1-3}$, HAIYANG XIE ${ }^{1-3}$ and SHUSEN ZHENG ${ }^{1-3}$ \\ ${ }^{1}$ Department of Surgery, Division of Hepatobiliary and Pancreatic Surgery, First Affiliated Hospital, School of Medicine, \\ Zhejiang University; ${ }^{2}$ Key Laboratory of Combined Multi-organ Transplantation, Ministry of Public Health; \\ ${ }^{3}$ Key Laboratory of Organ Transplantation, First Affiliated Hospital, School of Medicine, \\ Zhejiang University, Hangzhou, Zhejiang 310003, P.R. China
}

Received October 30, 2013; Accepted May 29, 2014

DOI: $10.3892 / \mathrm{mmr} .2014 .2703$

\begin{abstract}
The aim of this study was to investigate the effect of cyclosporine A (CsA) and tacrolimus (FK506) on interleukin-15 (IL-15) production during acute rejection following heart transplantation in mice. Inbred male Balb/c (H-2d) and C57BL/6 (H-2b) mice were used to establish a heterotopic intra-abdominal cardiac transplantation model. The mice were divided in four groups: syngeneic control, allogeneic acute rejection, allogeneic rejection treated with $\mathrm{CsA}$, and allogeneic rejection treated with FK506. The expression of IL-15, IL-2, and tumor necrosis factor- $\alpha(\mathrm{TNF}-\alpha)$ was measured using reverse transcription-polymerase chain reaction (RT-PCR) and western blotting. A low level of IL-15 was detected in transplanted hearts of the control group, with a significant increase observed in the allogeneic acute rejection group. Compared to the allogeneic acute rejection group, IL-15 expression was significantly decreased in the CsA-and FK506-treated allogeneic rejection groups. The TNF- $\alpha$ expression pattern was similar to that of IL-15 in all groups. IL-2 expression was increased in the allogeneic acute rejection group and was inhibited in mice treated with CsA and FK506. In conclusion, increased IL-15 expression in rejected murine heart grafts may be reduced by CsA and FK506 in vivo.
\end{abstract}

\section{Introduction}

Organ transplantation is considered the best option for treating patients who suffer from organ failure or dysfunction. However, the long-term allograft survival rate remains unsatisfactory due to alloimmune rejection reactions. Thus, treating acute rejection is the only option to improve the

Correspondence to: Dr Shusen Zheng, Department of Surgery, Division of Hepatobiliary and Pancreatic Surgery, First Affiliated Hospital, School of Medicine, Zhejiang University, 79 Qinchun Road, Hangzhou, Zhejiang 310003, P.R. China

E-mail: shusenzheng@zju.edu.cn

Key words: rejection, interleukin-15, heart transplantation, mice, cyclosporine A, FK506 long-term allograft survival rate. Acute allograft rejection is thought to be predominantly affected by T-cell mediated processes.

Interleukin-2 (IL-2) is considered to be the unique growth factor for T cells; however, rejection episodes are not always mediated by IL-2. Allograft rejection still occurs despite IL-2/IL-2R blockade (1), knockout of the $I L-2$ gene, and $I L-2 / I L-4$ double knockout $(2,3)$. This suggests that other cytokines may be involved in acute IL-2-negative anti-donor responses, such as IL-4, IL-7, IL-9 and IL-15, which can bind to the $\gamma$-chain of the IL-2 receptor (IL-2R) complex $(4,5)$.

IL-15 and IL-2 have similar structures. They share several biological activities, including stimulation of the proliferation and differentiation of $\mathrm{T}$ cells, and promotion of $\mathrm{T}$ cell chemotaxis (6-8). However, unlike IL-2, IL-15 is derived from a wide range of cell types, including activated macrophages, activated vascular endothelial cells, fibroblasts, muscle cells, and epithelial cells (9). Moreover, although IL-15 and IL- 2 share the same IL-2R $\beta$ and $\gamma$-chain receptor subunits, IL-15 has a unique $\alpha$-chain, IL-15R $\alpha$ (6-8). The role of IL-15 in allograft rejection is not clearly defined, although important roles for this cytokine have been suggested in other immunopathologies, such as infectious diseases (10), atherosclerosis (11), human immunodeficiency virus infection (12), and cancer (13-15). A number of studies have shown an increase in the expression of intragraft $I L-15$ mRNA in both IL-2-dependent and -independent allograft rejection cases, and suggested that increased IL-15 expression correlates with acute rejection $(2,3,16,17)$, particularly in the case of IL-2-independent rejection. These findings support the hypothesis that IL-15 may substitute IL-2 in the mechanism underlying IL-2-independent rejection.

Cyclosporine A (CsA) and tacrolimus (FK506), are two conventional immunosuppressant drugs widely used in the clinical setting, which are effective in not only preventing acute rejection, but also prolonging allograft survival time by inhibiting IL-2 production. However, the effect of CsA and FK506 on IL-15 production remains unclear. Although some in vitro studies have been performed, the results were inconsistent and contradictory (18-20). To date, no study exists that has examined the effects of CsA and FK506 on IL-15 expression in vivo. This study evaluated the effects of treatment with 
Table I. Oligonucleotide sequences for the amplification of mouse cytokine genes.

\begin{tabular}{|c|c|c|c|c|}
\hline Cytokine & $\begin{array}{l}\text { Product } \\
\text { size }(b p)\end{array}$ & & Primer sequences & PCR cycling conditions \\
\hline IL-2 & 408 & $\begin{array}{l}\text { Sense: } \\
\text { Antisense: }\end{array}$ & $\begin{array}{l}\text { 5'-AGC TCC ACT TCA AGC TCT AC-3' } \\
\text { 5'-GAC AGA AGG CTA TCC ATC TC-3' }\end{array}$ & $\begin{array}{l}94^{\circ} \mathrm{C}, 4 \mathrm{~min} \rightarrow 94^{\circ} \mathrm{C}, 30 \mathrm{sec}, \\
64^{\circ} \mathrm{C}, 30 \mathrm{sec}, 72^{\circ} \mathrm{C}, 30 \mathrm{sec} \\
(33 \text { cycles }) \rightarrow 72^{\circ} \mathrm{C}, 10 \mathrm{~min}\end{array}$ \\
\hline IFN- $\gamma$ & 300 & $\begin{array}{l}\text { Sense: } \\
\text { Antisense: }\end{array}$ & $\begin{array}{l}\text { 5'-TGG GGA CTG AAG TCC TAG AAG-3' } \\
\text { 5'-TTA CCC AGT CAG GGT TAC TGC TGC TGT G-3' }\end{array}$ & $\begin{array}{l}94^{\circ} \mathrm{C}, 4 \mathrm{~min} \rightarrow 94^{\circ} \mathrm{C}, 60 \mathrm{sec}, \\
57^{\circ} \mathrm{C}, 60 \mathrm{sec}, 72^{\circ} \mathrm{C}, 60 \mathrm{sec} \\
(26 \text { cycles }) \rightarrow 72^{\circ} \mathrm{C}, 10 \mathrm{~min}\end{array}$ \\
\hline IL-15 & 345 & $\begin{array}{l}\text { Sense: } \\
\text { Antisense: }\end{array}$ & $\begin{array}{l}\text { 5'-TCC ATC TCG TGC TAC TTG TG-3' } \\
\text { 5'-CAT TCC TTG CAG CCA GAT TC-3' }\end{array}$ & $\begin{array}{l}94^{\circ} \mathrm{C}, 4 \mathrm{~min} \rightarrow 94^{\circ} \mathrm{C}, 30 \mathrm{sec}, \\
66^{\circ} \mathrm{C}, 30 \mathrm{sec}, 72^{\circ} \mathrm{C}, 30 \mathrm{sec} \\
(29 \text { cycles }) \rightarrow 72^{\circ} \mathrm{C}, 10 \mathrm{~min}\end{array}$ \\
\hline TNF- $\alpha$ & 446 & $\begin{array}{l}\text { Sense: } \\
\text { Antisense: }\end{array}$ & $\begin{array}{l}\text { 5'-AGC CCA CGT AGC AAA CCA CCA A-3' } \\
\text { 5'-ACA CCC ATT CCC TTC ACA GAG CAA T-3' }\end{array}$ & $\begin{array}{l}94^{\circ} \mathrm{C}, 4 \mathrm{~min} \rightarrow 94^{\circ} \mathrm{C}, 30 \mathrm{sec}, \\
64^{\circ} \mathrm{C}, 30 \mathrm{sec}, 72^{\circ} \mathrm{C}, 30 \mathrm{sec} \\
(33 \text { cycles }) \rightarrow 72^{\circ} \mathrm{C}, 10 \mathrm{~min}\end{array}$ \\
\hline$\beta$-actin & 539 & $\begin{array}{l}\text { Sense: } \\
\text { Antisense: }\end{array}$ & $\begin{array}{l}\text { 5'-GTG GGC CGC CCT AGG CAC CAA-3' } \\
\text { 5'-CTC TTT GAT GTC ACG CAC GAT TTC-3' }\end{array}$ & $\begin{array}{l}94^{\circ} \mathrm{C}, 4 \mathrm{~min} \rightarrow 94^{\circ} \mathrm{C}, 30 \mathrm{sec}, \\
62^{\circ} \mathrm{C}, 30 \mathrm{sec}, 72^{\circ} \mathrm{C}, 30 \mathrm{sec} \\
(28 \text { cycles }) \rightarrow 72^{\circ} \mathrm{C}, 10 \mathrm{~min}\end{array}$ \\
\hline
\end{tabular}

PCR, polymerase chain reaction; IL-2, interleukin-2; IFN- $\gamma$, interferon- $\gamma$; TNF- $\alpha$, tumor necrosis factor- $\alpha$; bp, base pair.

CsA and FK506 on the alloimmune responses following heart transplantation in mice, and specifically showed that IL-15 expression is inhibited by both drugs.

\section{Materials and methods}

Drugs. Stock solutions of CsA and FK506 were prepared as follows: CsA was purchased from Novartis Pharmaceuticals (Basel, Switzerland), and was dissolved in physiological saline to obtain a working concentration of $0.4 \mathrm{mg} / \mathrm{ml}$. The FK506 stock (Fujisawa Pharmaceutical, Osaka Japan) was suspended in phosphate-buffered saline (PBS) to obtain a working concentration of $0.08 \mathrm{mg} / \mathrm{ml}$.

Animals and groups. C57BL/6 (H-2b) and Balb/c (H-2d) mice, 6-8 weeks old, weighing 18-20 g, were purchased from the Shanghai Laboratory Animal Center of the Chinese Academy of Sciences, and were housed in cages inside a room with a light/dark cycle. Heterotopic intra-abdominal cardiac transplantation was performed with the method reported by (21), with some modifications. Briefly, the hearts of the C57 mice were transplanted into the abdominal cavities of the Balb/c mice, the aortic ascent artery of the C57 mice was connected to the abdomnal aortic artery of the $\mathrm{Balb} / \mathrm{c}$ mice, and the main pulmonary artery of the C57 mice was connected to the inferior cavae vein of the Balb/c mice. Balb/c (H-2d) mice that received the transplant were randomly divided in four groups: syngeneic control group, where donors were Balb/c mice; allogeneic acute rejection group, where donors were C57BL/6 mice; allogeneic CsA treatment group, where donors were $\mathrm{C} 57 \mathrm{BL} / 6$ mice and treatment with CsA was performed by intraperitoneal injection of $10 \mathrm{mg} / \mathrm{kg} /$ day CsA from the day of operation [post-operative day (POD) 0] to POD 13; and allogeneic FK506 treatment group, where donors were $\mathrm{C} 57 \mathrm{BL} / 6$ mice and recipients were treated with FK506 $1.0 \mathrm{mg} / \mathrm{kg} /$ day by intraperitoneal injection from POD 0 to POD 13. Each of these four groups was subdivided into four groups $(\mathrm{n}=5)$ corresponding to PODs 1 , 3,5 and 7 for sample harvesting, and additional subgroups $(n=6)$ for general observations and measurement of graft survival time. The graft survival time was assessed daily by palpation of the heart graft. All experiments were approved by the Animal Welfare Committee and were performed according to the Laboratory Animal Management Guidelines of the Zhejiang University.

RNA extraction and reverse transcription $(R T)$. For RT-polymerase chain reaction (PCR) analysis, specimens were snap frozen in liquid nitrogen and stored at $-80^{\circ} \mathrm{C}$. Total RNA was extracted with the Gibco ${ }^{\circledR}$ TRIzol reagent according to the manufacturer's instructions (Thermo Fisher Scientific, Waltham, MA, USA). First strand cDNA synthesis was performed as follows: $4 \mu \mathrm{g}$ isolated RNA and $3 \mu \mathrm{l}$ random primers (Fermentas, Thermo Fisher Scientific, Waltham, MA, USA) were mixed with double distilled (dd) $\mathrm{H}_{2} \mathrm{O}$, in order to obtain a final volume of $11 \mu \mathrm{l}$. The reaction mixture was incubated at $70^{\circ} \mathrm{C}$ for $5 \mathrm{~min}$, and at $0^{\circ} \mathrm{C}$ for $5 \mathrm{~min}$. A total of $5 \mu \mathrm{l}$ 5X MMLV-RT reaction buffer, $2 \mu 110 \mathrm{mM}$ dNTP, $1 \mu 1$ $\mathrm{ddH}_{2} \mathrm{O}$ and $1 \mu \mathrm{l}$ MMLV Reverse Transcriptase (Fermentas) was subsequently added and the samples were incubated at $42^{\circ} \mathrm{C}$ for $60 \mathrm{~min}$, and at $70^{\circ} \mathrm{C}$ for $10 \mathrm{~min}$ to terminate the reaction. The synthesized cDNA was stored at $-20^{\circ} \mathrm{C}$.

PCR analysis. PCR analysis was conducted as follows: synthesized cDNA $(2 \mu \mathrm{l})$ was amplified in a $25 \mu \mathrm{l}$ reaction volume containing sense and anti-sense primers of each cytokine 

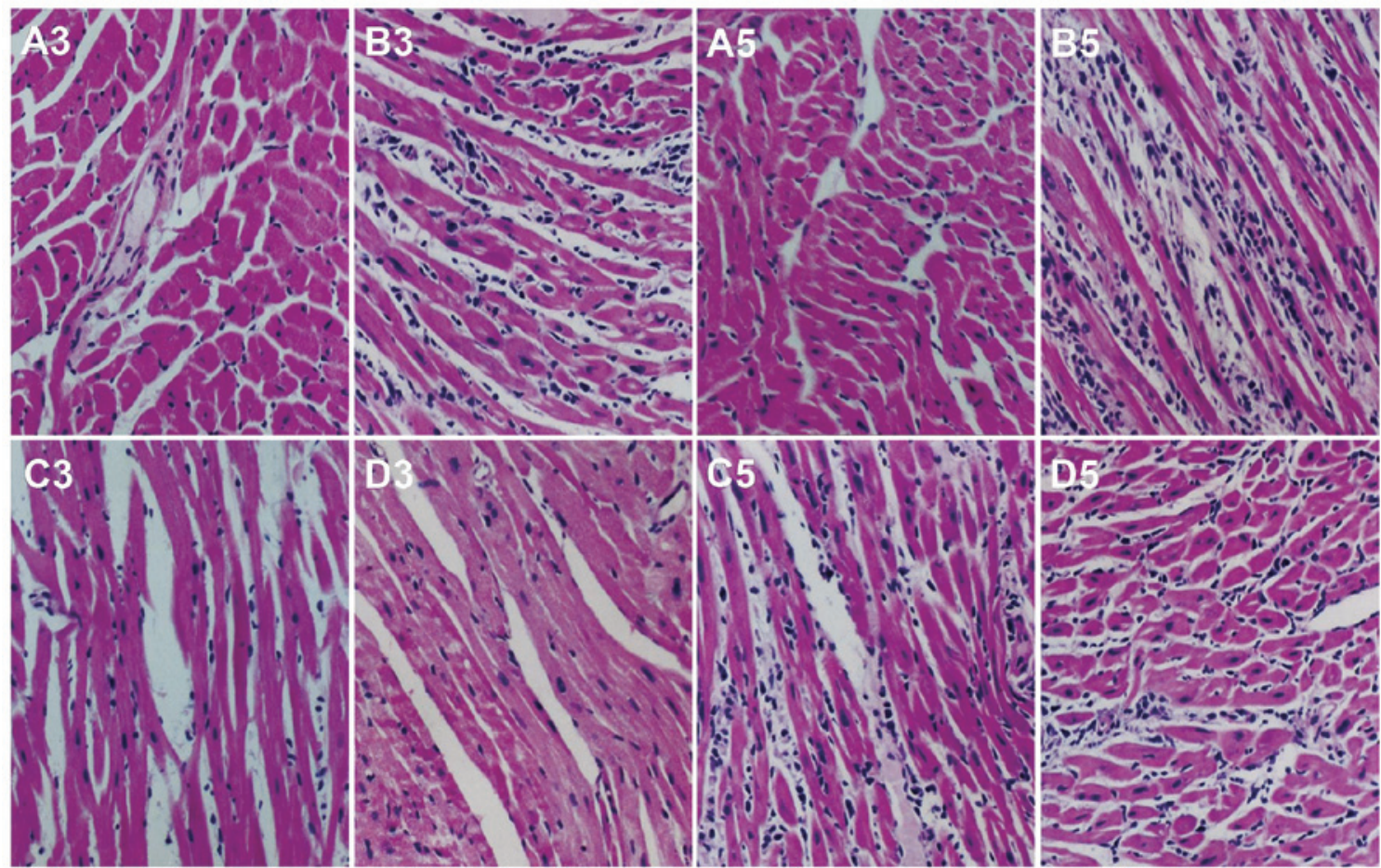

Figure 1. Histological examination of the murine heart grafts, hematoxylin and eosin staining (original magnification, x200). A, syngeneic control group; B, allogeneic acute rejection group; C, allogeneic cyclosporine A (CsA) treatment group; D, allogeneic tacrolimus (FK506) treatment group. The numbers 3 and 5 in each group refer to the post-operative day (POD) in which the samples were harvested. On POD 3, the heart grafts have a normal histological appearance and show no sign of rejection in the syngeneic control, CsA treatment, and FK506 treatment groups. However, some lymphocyte infiltration and rejection occurs in the heart grafts of the allogeneic acute rejection group. On POD 5, the heart grafts have a normal histological appearance in the syngeneic control group, and rejection occurs in the other groups. Compared to the allogeneic acute rejection group, the degree of lymphocyte infiltration is markedly reduced in the CsA and FK506 treatment groups.

(Table 1). The reagents were used first to rule out failure of the reverse transcriptase reaction and PCR amplification, and second to detect gross variation in cDNA quantity among the samples. The samples were amplified in a PTC-200 Peltier Thermal cycler (MJ Research, Inc., Watertown, MA, USA). The conditions were optimized for each primer pair to avoid the amplification of non-specific products (Table I).

Semi-quantitative mRNA analysis. Amplified products and the Fermentas ${ }^{\circledR}$ pUC19 DNA/MspI (HpAII) marker 23 (Thermo Fisher Scientific) were analyzed by electrophoresis on $1.5 \%$ agarose gels containing ethidium bromide. Images of the gels were acquired and the band intensity was analyzed using the Kodak analysis of the gel image software (Life Technologies, Grand Island, NY, USA). To correct for variations in the mRNA concentration in each sample, the densitometry value for each cytokine was divided by the corresponding value of $\beta$-actin.

Protein extraction, titration and storage. The heart grafts were lysed in ice-cold tissue lysis buffer, containing $0.25 \%$ NP-40, $125 \mathrm{mM} \mathrm{KCl}, 10 \mathrm{mM} \mathrm{MgCl}$, $60 \mathrm{mM}$ HEPES (pH 7.9), $0.5 \mathrm{mM}$ DTT, $0.5 \mathrm{mM}$ phenylmethylsulfonyl fluoride, $10 \mu \mathrm{g} / \mathrm{l}$ aprotinin and $10 \mu \mathrm{g} / 1$ leupeptin (all Sangon Biotech Co., Ltd., Shanghai, China). The cell debris was removed by centrifugation and the protein-containing supernatant was removed and titrated according to the specifications of the $\mathrm{DC}^{\mathrm{TM}}$ Protein Assay kit (Bio-Rad Laboratories, Inc., Hercules, CA, USA), and stored at $-80^{\circ} \mathrm{C}$.
Table II. The survival time of heart grafts in the different groups.

\begin{tabular}{lcc}
\hline Group & $\mathrm{n}$ & Survival time $^{\mathrm{a}}\left(\mathrm{n}^{\mathrm{b}}\right)$ \\
\hline A & 8 & $100(8)$ \\
B & 7 & $7(2), 8(3), 9(2)$ \\
C & 6 & $15,16,18,23,24,25$ \\
D & 6 & $15,17,18,19,20,15$
\end{tabular}

${ }^{a}$ time expressed in days; ${ }^{b} \mathrm{n}=1$ unless stated otherwise. A, syngeneic control group; B, allogeneic acute rejection group; C, allogeneic cyclosporine A treatment group; D, allogeneic tacrolimus (FK506) treatment group.

Western blotting. The proteins were subjected to $15 \%$ sodium dodecyl sulfate-polyacrylamide gel electrophoresis, and transferred to nitrocellulose membranes (EMD Millipore, Billerica, MA, USA). The membranes were blocked with 5\% nonfat dry milk in PBS and incubated with biotinylated goat anti-mouse IL-15 antibody (1:1,000; R\&D Systems, Minneapolis, MN, USA) or mouse anti-mouse tumor necrosis factor- $\alpha$ (TNF- $\alpha$ ) antibody (1:1,000; Perbio Science AB, Helsingborg, Sweden) at $4{ }^{\circ} \mathrm{C}$ overnight. After washing with PBS, the membranes were incubated with horseradish peroxidase (HRP)-conjugated anti-goat or anti-mouse immunoglobulin (Ig)G (both at 1:1,500; Dako, Glostrup, Denmark). The bands were visualized using 

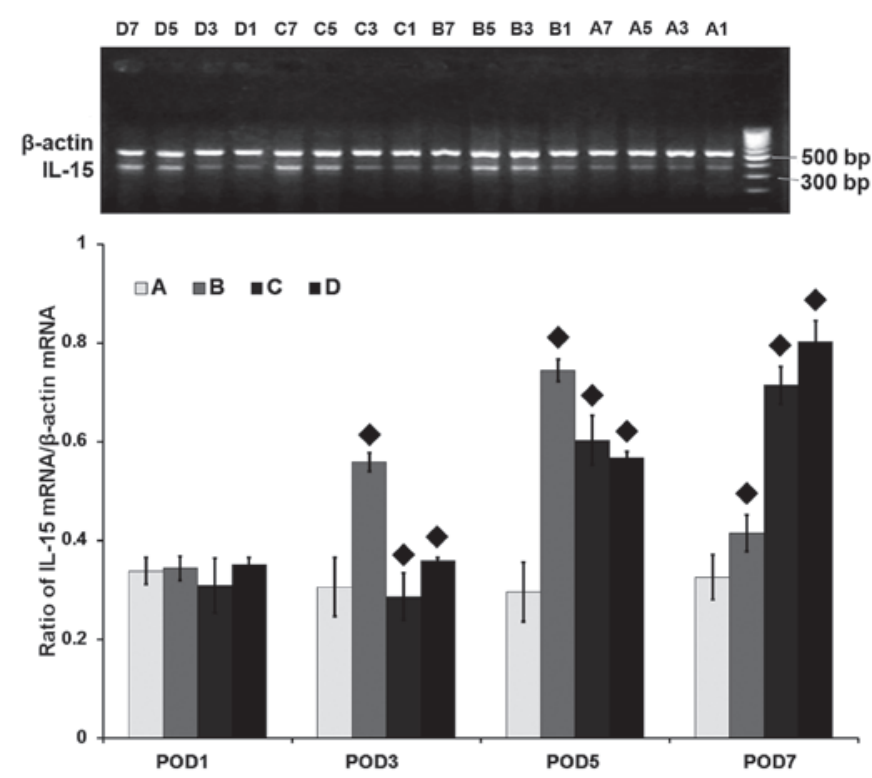

Figure 2. mRNA level of the interleukin-15 gene (IL-15) assessed by reverse transcription-polymerase chain reaction in the heart grafts. A, syngeneic control group; $\mathrm{B}$, allogeneic acute rejection group; $\mathrm{C}$, allogeneic cyclosporine A (CsA) treatment group; D, allogeneic tacrolimus (FK506) treatment group. The numbers 1, 3,5 and 7 in each group refer to the post-operative day (POD) in which the samples were harvested. indicates statistical significance $(\mathrm{P}<0.001)$ on pairwise comparison assessed by a t-test. The $I L-15$ gene is expressed at low levels in the syngeneic control group at all time-points or on POD 1 in the other groups. The $I L-15$ mRNA level is significantly increased in the allogeneic acute rejection group on PODs 3, 5 and 7 (all, $\mathrm{P}<0.05$ ), with its highest level reached on POD 5. Compared to the allogeneic acute rejection group, the $I L-15$ expression in the CsA and FK506 treatment groups is significantly decreased on PODs 3 and 5 (all, $\mathrm{P}<0.001$ ), and is again increased on POD 7 (both, $\mathrm{P}<0.001$ ).

the Enhanced Chemiluminescence Blotting system (Santa Cruz Biotechnology, Inc., Dallas, TX, USA). The blots were developed on X-ray film (Eastman Kodak, Rochester, NY, USA).

Histologic evaluation. Heart grafts were excised, covered with formalin, embedded in paraffin wax, sectioned and stained with hematoxylin and eosin. They were then observed under a microscope (Leica DM3000; Leica Microsystems, Wetzlar, Germany).

Statistical analysis. Results were expressed as the mean \pm standard deviation (SD). Statistical analysis was performed with the SPSS software (SPSS Inc., Chicago, IL, USA). Independent-sample t-tests and one-way analysis of variance (ANOVA) were used for comparisons between groups of parametric data. A p-value $(\mathrm{P})$ of $<0.05$ was considered to indicate a statistically significant difference.

\section{Results}

Heart graft survival time. The heart graft survival times were all longer than 100 days in the control group. In the allogeneic acute rejection group, the heart grafts stopped working by POD 7-9 ( $8 \pm 0.9$ days). The mean heart graft survival times of the CsA and FK506 treatment groups were 20.2 \pm 4.4 and $17.3 \pm 2.1$ days, respectively (Table II), which are significantly higher compared to the allogeneic acute rejection group

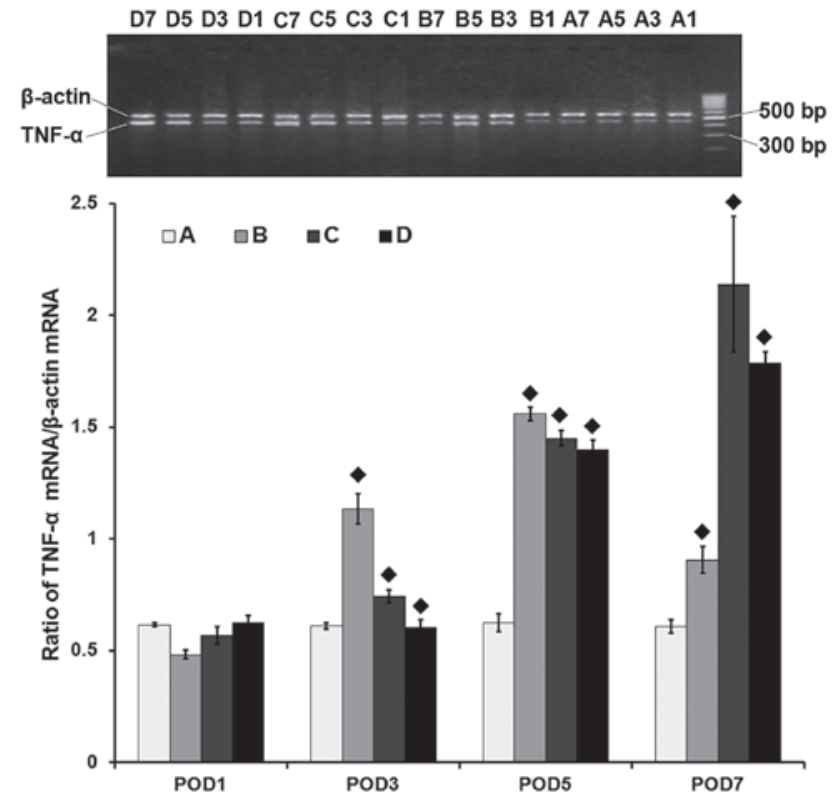

Figure 3. mRNA level of the tumor necrosis factor- $\alpha$ gene $(T N F-\alpha)$ assessed by reverse transcription-polymerase chain reaction in the heart grafts. A, syngeneic control group; $\mathrm{B}$, allogeneic acute rejection group; C, allogeneic cyclosporine A (CsA) treatment group; D, allogeneic tacrolimus (FK506) treatment group. The numbers 1,3,5 and 7 in each group refer to the post-operative day (POD) in which the samples were harvested. indicates statistical significance $(\mathrm{P}<0.001)$ on pairwise comparison assessed by a t-test. The $T N F$ - $\alpha$ gene is expressed at low levels in the syngeneic control group at all time-points or at POD 1 in the other groups. The TNF- $\alpha$ mRNA level is significantly increased in the allogeneic acute rejection group on PODs 3,5 and 7 (all, $\mathrm{P}<0.001$ ), with its highest level reached on POD 5. Compared to the allogeneic acute rejection group, $T N F-\alpha$ expression in the CsA and FK506 treatment groups is significantly decreased on PODs 3 and 5 (all, $\mathrm{P}<0.001$ ), and is again increased on POD 7 (both, $\mathrm{P}<0.001$ ).

$(\mathrm{P}<0.001)$. However, the heart graft survival time did not differ significantly between the CSA and FK506 treatment groups $(\mathrm{P}=0.1)$.

Histology. No signs of rejection were detected at any time-point in the control group. Myocardial lymphocyte infiltration was observed in the heart grafts from PODs 3 to 7 in the allogeneic acute rejection group. Rejection was markedly suppressed in the transplanted hearts of the CsA and FK506 treatment groups, with marked mononuclear infiltration observed (Fig. 1).

Cytokine mRNA expression. The $I L-15$ mRNA was detected at low levels in the transplanted hearts of the control group at all postoperative time-points. Compared to the control group, the $I L-15$ expression was significantly increased in the allogeneic acute rejection group on PODs 3,5 and $7(\mathrm{P}=0.02, \mathrm{P}<0.001$ and $\mathrm{P}=0.03$, respectively). The expression of $I L-15 \mathrm{mRNA}$ peaked on POD 5 in the allogeneic acute rejection group. In the CsA and FK506 treatment groups, the $I L-15$ mRNA was detected at low levels on PODs 1 and 3, but its level increased from PODs 5 to 7. Compared to the allogeneic acute rejection group, the expression of $I L-15$ was significantly inhibited on PODs 3 and 5 in the CsA and FK506 treatment groups (Fig. 2). The expression pattern of the TNF- $\alpha$ mRNA was similar to that of $I L-15$ in all groups (Fig. 3). The $I L-2$ mRNA level was undetectable in the control group and significantly increased in the allogeneic acute rejection group on PODs 3,5 and 7 (all, 

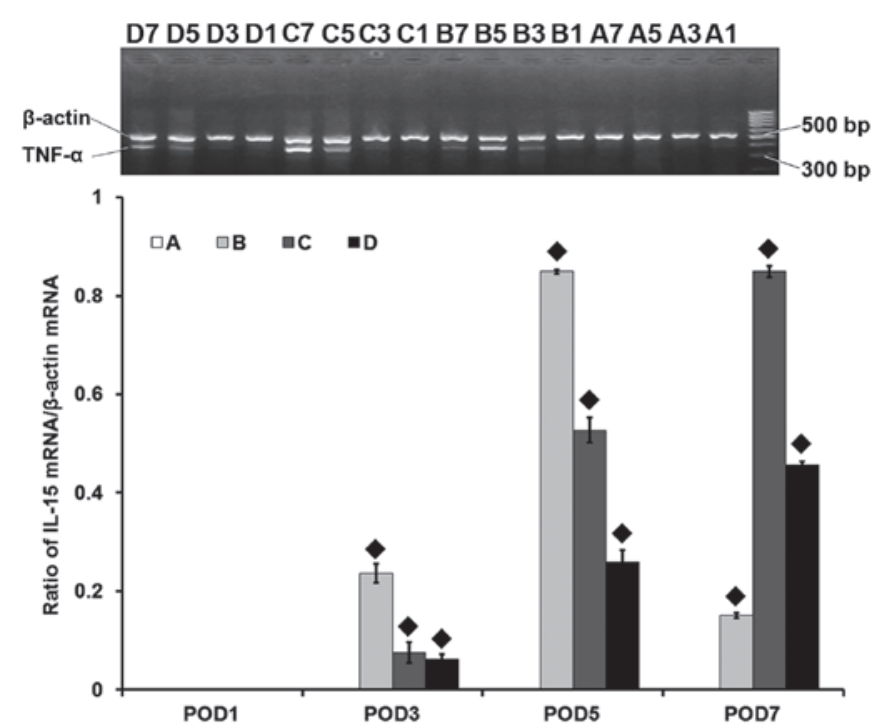

Figure 4. mRNA level of the interleukin-2 gene (IL-2) assessed by reverse transcription-polymerase chain reaction in the heart grafts. A, syngeneic control group; B, allogeneic acute rejection group; C, allogeneic cyclosporine $\mathrm{A}$ (CsA) treatment group; D, allogeneic tacrolimus (FK506) treatment group. The numbers $1,3,5$ and 7 in each group refer to the post-operative day (POD) in which the samples were harvested. indicates statistical significance $(\mathrm{P}<0.001)$ on pairwise comparison assesssed by a t-test. The $I L-2$ mRNA is not detected in the syngeneic control group at any time point or on POD 1 in the other groups. Its level is significantly increased in the allogeneic acute rejection group on PODs 3, 5 and 7 (all, $\mathrm{P}<0.001$,) reaching its highest level on POD 5. Compared to the allogeneic acute rejection group, $I L-2$ expression in the CsA and FK506 treatment groups is significantly decreased on PODs 3 and 5 (all, $\mathrm{P}<0.001$ ), and is again increased on POD 7 (both, $\mathrm{P}<0.001)$.

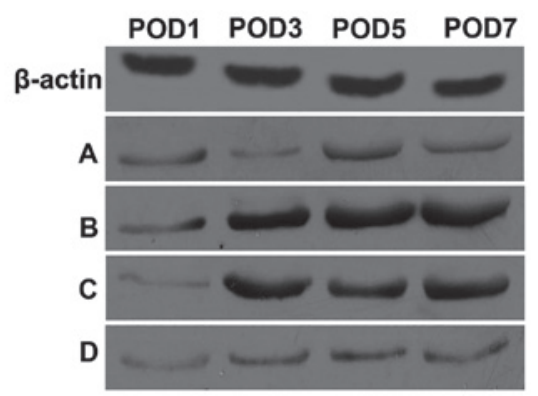

Figure 5. Interleukin-15 (IL-15) western blot. A, syngeneic control group $\mathrm{B}$, allogeneic acute rejection group; $\mathrm{C}$, allogeneic cyclosporine A (CsA) treatment group; D, allogeneic tacrolimus (FK506) treatment group. The IL-15 protein is expressed at low levels in the syngeneic control group at all time-points. Compared to the syngeneic control group, IL-15 protein expression is increased from postoperative day (POD) 3 and until POD 7 in the allogeneic acute rejection group. In the CsA and FK506 treatment groups, IL-15 protein expression is decreased at all time-points compared to the allogeneic acute rejection group.

$\mathrm{P}<0.001$ ), with a peak on POD 5. In the CsA and FK506 treatment groups, the $I L-2$ mRNA could not be detected on PODs 1 and 3 , but ts level increased from PODs 5 to 7 . Compared to the allogeneic acute rejection group, the $I L-2$ expression was significantly inhibited on PODs 3 and 5 in the CsA and FK506 treatment groups (Fig. 4).

Cytokine protein expression. Low levels of the IL-15 and $\mathrm{TNF}-\alpha$ proteins were detected in the heart grafts of the control

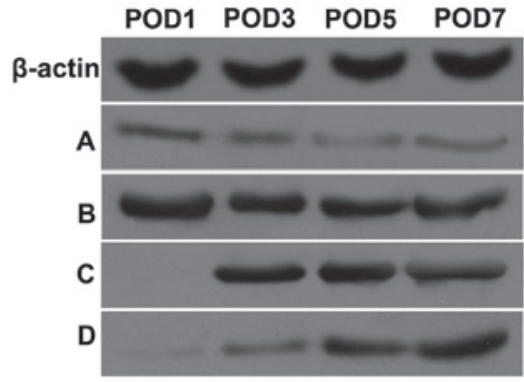

Figure 6. Tumor necrosis factor- $\alpha$ (TNF- $\alpha$ western blot. A, syngeneic control group; B, allogeneic acute rejection group; $\mathrm{C}$, allogeneic cyclosporine A (CsA) treatment group; D, allogeneic tacrolimus (FK506) treatment group. The TNF- $\alpha$ protein is expressed at low levels in the syngeneic control group at all time-points. Compared to the syngeneic control group, TNF- $\alpha$ protein expression is increased from postoperative day (POD) 1 and until POD 7 in the allogeneic acute rejection group. In the CsA and FK506 treatment groups, TNF- $\alpha$ protein expression is decreased at all time-points compared to the allogeneic acute rejection group.

group at all time-points. Compared to the control group, IL-15 protein expression was significantly increased from PODs 3 to 7 , and TNF- $\alpha$ protein expression was increased from PODs 1 to 7 in the heart grafts of the allogeneic acute rejection group. In the CsA and FK506 treatment groups, despite the gradual and slight increase from PODs 3 to 7, the expression of IL-15 (Fig. 5) and TNF- $\alpha$ (Fig. 6) was reduced at all time-points relative to the allogeneic acute rejection group.

\section{Discussion}

IL-15, a T cell growth factor, is derived from non-lymphocytes, such as activated macrophages, activated vascular endothelial cells, fibroblasts, and muscle cells. It shares a number of common biological activities with IL-2, including stimulation of T cell, B cell, and natural killer cell proliferation, as well as a $\mathrm{T}$ cell chemoattractant activity (6-8). Recent studies showed that IL-15 expression is increased in certain types of immune-mediated tissue injury, such as allograft rejection $(4,5,10-12,15)$. There is considerable interest in the potential role of this cytokine in the pathogenesis of tissue destruction, particularly in the context of alloimmune reactions.

In the present study, the level of the $I L-15 \mathrm{mRNA}$ was low but still detectable in non-rejected heart grafts in the syngeneic control group, whereas it was significantly increased in rejected heart grafts in the acute rejection group. The low level of $I L-15$ mRNA expressed may be attributed to cardiac muscle cells, which produce low levels of IL-15 (22). The increased level of $I L-15$ mRNA is likely primarily derived from the infiltrating activated monocytes/macrophages in the rejected heart graft, since these cells produce high levels of IL-15 (22). Numerous monocyte/macrophage infiltrates are observed in acutely rejected allografts $(23,24)$. Unlike $I L-15$, the expression of $I L-2$ was not detected in non-rejected heart grafts and was significantly increased in rejected heart grafts. The difference between the expression patterns of $I L-15$ and $I L-2$ may be due to the origin of these two cytokines.

Increased $I L-15$ expression appeared associated with the presence of acute rejection in the present study. The strongest expression of the $I L-15$ gene was observed on POD 5, the same 
day at which lymphocyte infiltration peaked in the rejected heart grafts according to the pathological examination.

It is well known that both CsA and FK506 can inhibit IL-2 expression and prolong allograft survival time by blocking calcineurin $(25,26)$. However, the relationship between IL-15 expression and the administration of CsA or FK506 is rarely reported, and only three in vitro studies have been performed $(18-20)$; two of these $(19,20)$ reported that the production of IL-15 is unaffected by CsA, but one (18) reported that CsA administration decreases the level of IL-15 in a dose-dependent manner. The contradictory results between these studies may be due to the different cell lines used. In the present study, we demonstrated that IL-15 expression, at both the mRNA and the protein level, is reduced by CsA or FK506 treatment (Figs. 2 and 5). However, we observed a discordance between IL-15 mRNA and protein expression. In the allogeneic acute rejection group, the $I L-15$ mRNA level was increased on POD 3, peaked on POD 5, and decreased on POD 7, although the expression of IL-15 was not completely blocked. Notably, on POD 7, the $I L-15$ expression in the heart grafts treated with CsA and FK506 increased again. This finding may be related to the dose of the immunosuppressants used in this study. It is likely that CsA or FK506 induce a decrease in the level of $I L-15$ in a dose-dependent manner in vivo, and increased doses of CsA or FK506 may result in complete inhibition of $I L-15$. However, the mechanism by which CsA or FK506 inhibit the expression of $I L-15$ remains unclear. In addition, the present study showed that the TNF- $\alpha$ mRNA derived from activated monocytes/macrophages is significantly reduced upon administration of CsA and FK506. This finding indicates that the activity of macrophages may be suppressed in these conditions. We conclude that CsA and FK506 may affect the production of IL-15 via interactions with the macrophages.

In conclusion, IL-15, a non-T cell-derived cytokine, is involved in acute rejection following heart transplantation and is partially downregulated in vivo in mice by CsA and FK506 treatment. Whether increased doses of CsA or FK506 may result in the complete inhibition of IL-15 production requires further study, while it is also necessary to clarify the relationship between CsA or FK506 treatment and IL-15 expression in clinical studies.

\section{Acknowledgements}

This study was supported by grants from the Team Program of Science and the Health Bureau of the Zhejiang Province Foundation (B1652).

\section{References}

1. van Gelder T, Baan CC, Balk AH, et al: Blockade of the interleukin (IL)-2/IL-2 receptor pathway with a monoclonal anti-IL-2 receptor antibody (BT563) does not prevent the development of acute heart allograft rejection in humans. Transplantation 65 : 405-410, 1998.

2. Li XC, Roy-Chaudhury P, Hancock WW, et al: IL-2 and IL-4 double knockout mice reject islet allografts: a role for novel T cell growth factors in allograft rejection. J Immunol 161: 890-896, 1998.
3. Steiger J, Nickerson PW, Steurer W, Moscovitch-Lopatin M and Strom TB: IL-2 knockout recipient mice reject islet cell allografts. J Immunol 155: 489-498, 1995.

4. Lewis EC, Weiler M, Tejman-Yarden N, et al: Involvement of graft-derived interleukin-15 in islet allograft rejection in mice. Cytokine 34: 106-113, 2006.

5. Zheng XX, Gao W, Donskoy E, et al: An antagonist mutant IL-15/Fc promotes transplant tolerance. Transplantation 81: 109-116, 2006.

6. Ikemizu S, Chirifu M and Davis SJ: IL-2 and IL-15 signaling complexes: different but the same. Nat Immunol 13: 1141-1142, 2012.

7. Ring AM, Lin JX, Feng D, et al: Mechanistic and structural insight into the functional dichotomy between IL-2 and IL-15. Nat Immunol 13: 1187-1195, 2012.

8. Waldmann TA: The IL-2/IL-15 receptor systems: targets for immunotherapy. J Clin Immunol 22: 51-56, 2002.

9. Grabstein KH, Eisenman J, Shanebeck K, et al: Cloning of a $T$ cell growth factor that interacts with the beta chain of the interleukin-2 receptor. Science 264: 965-968, 1994.

10. Di Sabatino A, Calarota SA, Vidali F, MacDonald TT and Corazza GR: Role of IL-15 in immune-mediated and infectious diseases. Cytokine Growth Factor Rev 22: 19-33, 2011.

11. van Es T, van Puijvelde GH, Michon IN, et al: IL-15 aggravates atherosclerotic lesion development in LDL receptor deficient mice. Vaccine 29: 976-983, 2011.

12. d'Ettorre G, Andreotti M, Ceccarelli G, et al: The role of IL-15 in challenging Acquired Immunodeficiency Syndrome. Cytokine 57: 54-60, 2012.

13. Croce M, Orengo AM, Azzarone B and Ferrini S: Immunotherapeutic applications of IL-15. Immunotherapy 4: 957-969, 2012.

14. Roberti MP, Rocca YS, Amat M, et al: IL-2- or IL-15-activated NK cells enhance Cetuximab-mediated activity against triple-negative breast cancer in xenografts and in breast cancer patients. Breast Cancer Res Treat 136: 659-671, 2012.

15. Steel JC, Waldmann TA and Morris JC: Interleukin-15 biology and its therapeutic implications in cancer. Trends Pharmacol Sci 33: 35-41, 2012.

16. Baan CC, van Riemsdijk-Overbeeke IC, Boelaars-van Haperen MJ, IJzermans JM and Weimar W: Inhibition of the IL-15 pathway in anti-CD25 mAb treated renal allograft recipients. Transpl Immunol 10: 81-87, 2002.

17. Smith XG, Bolton EM and Bradley JA: Targeting IL-15 as a therapeutic strategy in organ transplant rejection. Curr Opin Investig Drugs 3: 406-410, 2002.

18. Cho ML, Kim WU, Min SY, et al: Cyclosporine differentially regulates interleukin-10, interleukin-15, and tumor necrosis factor $\alpha$ production by rheumatoid synoviocytes. Arthritis Rheum 46: 42-51, 2002.

19. Lewis E, Weiler M, Chaimovitz C and Douvdevani A: Interleukin-15 is the main mediator of lymphocyte proliferation in cultures mixed with human kidney tubular epithelial cells. Transplantation 72: 886-890, 2001.

20. Stoeck M, Schäfer M, Hofmann HP and Gekeler V: Dexamethasone and cyclosporin A do not inhibit interleukin-15 expression in the human lung carcinoma cell line A549. Eur Cytokine Netw 11: 414-419, 2000.

21. Ono K and Lindsey ES: Improved technique of heart transplantation in rats. J Thorac Cardiovasc Surg 57: 225-229, 1969.

22. Giri JG, Ahdieh M, Eisenman J, et al: Utilization of the beta and gamma chains of the IL-2 receptor by the novel cytokine IL-15. EMBO J 13: 2822-2830, 1994.

23. Hubscher SG: Histological findings in liver allograft rejection - new insights into the pathogenesis of hepatocellular damage in liver allografts. Histopathology 18: 377-383, 1991.

24. McCaughan GW, Davies JS, Waugh JA, et al: A quantitative analysis of $\mathrm{T}$ lymphocyte populations in human liver allografts undergoing rejection: the use of monoclonal antibodies and double immunolabeling. Hepatology 12: 1305-1313, 1990.

25. Wiederrecht G, Lam E, Hung S, Martin M and Sigal N: The mechanism of action of FK-506 and cyclosporin A. Ann NY Acad Sci 696: 9-19, 1993.

26. Yamamoto $\mathrm{S}$ and Kato R: Hair growth-stimulating effects of cyclosporin A and FK506, potent immunosuppressants. J Dermatol Sci (Suppl): S47-S54, 1994. 